\title{
Relationship Between Internal Audit Practices And Performance Of Water Service Providers In Kenya
}

\author{
Perminus Nyaga Ndimitu \\ PhD Candidate, Department of Finance and Accounting, \\ School of Business, University of Nairobi \\ Dr. Cyrus Iraya Mwangi \\ Department of Finance and Accounting, \\ School of Business, University of Nairobi \\ Dr. Sifunjo Kisaka \\ Department of Finance and Accounting, \\ School of Business, University of Nairobi \\ Dr. Mirie Mwangi \\ Department of Finance and Accounting, \\ School of Business, University of Nairobi
}

\begin{abstract}
The purpose of this study was to establish the relationship between internal audit and organisational performance of Kenyan WSPs. To fulfil the study objective, hypothesis was derived and tested on a population of 93 Water service providers. This cross sectional descriptive study was guided by a positivist study paradigm. The Data Envelopment Analysis approach was used to codify the dependent variable and regression analysis was then applied to test the hypothesis. The null hypothesis was rejected as the regression analysis found that $10.1 \%$ of variations in firm performance are explained by variation in internal audit while $89.9 \%$ of variations are explained by other variables. This infers that internal audit influences performance of Water service providers in Kenya. The study made contribution to policy formulation and development to benefit the understanding on how internal audit in the Kenyan context influence organizational performance resulting to formulation of reforms in various public institutions to strengthen internal audit.
\end{abstract}

Keywords: Internal Audit Practices, Firm Performance, Water Service Providers

\section{INTRODUCTION}

The relationship between internal audit and firm performance has gradually created interest in Water service provider's management study (Al Matari, Swidi \& Fadzil, 2014). Internal audit is an essential part of management and a tool for enhancing performance of organisations. Complex organisational structures demand competent and professional internal audit to ensure that scarce resources are utilized efficiently and effectively to enhance organisational performance (Chan, 2004). From the literature reviewed, there is sufficient empirical and theoretical evidence that internal audit influences organisational performance (Cohen \& Sayag, 2010; Eko \& Hariyanto, 2011; Theofaris et al., 2011). However, internal audit alone may not adequately explain variation in performance of companies. This shows that some other elements mediate to catalyse, decelerate or moderate the association between internal audit and firm performance. 
Water service providers (WSPs) are legal public bodies licensed by Water Regulatory Boards (WRB) to offer water and sanitation services within their mandated areas. This is provided for in section 46 of Water Act of 2002 of the laws of Kenya. Water service providers therefore are vehicles useful to the government in order to achieve its goals to provide piped water to every home by the year 2030. Internal audit is an independent and objective appraisal, assurance and consulting function intended to improve and develop an organisations performance (IIA, 1999; Reid \& Ashelby, 2002). It assists an organisation accomplish its goals by introducing an orderly, efficient method to assess and enhance the efficacy of risk assessment and control process. Internal audit practice is an independent and objective appraisal activity established within an entity to examine and evaluate its operations as a service to the organization (Subramaniam, 2006). Its aim is to assure management that the internal controls are adequate and operating satisfactorily (Reid \& Ashelby, 2002).

Duffy, Fitzsimmons and Jain (2006) define organisational performance as the organisations capability to achieve its goals by means of resources effectively and efficiently. Performance of organizations is measured by outcomes achieved and determinants of that performance by assessing the efficiency with which that performance is achieved (Bethan et al, 2004). It is the extent to which a company achieves a set of pre- determined targets that are unique to its mission. Explaining and often predicting firm performance is a primary study objective of most management study. Organizational efficiency is a recurrent theme in most branches of management (Venkatramann and Ramanujam, 1981). Explaining and often predicting organizational performance is a primary research objective of most management research (March and Sutton, 1997). It has however become a contentious subject among organizational researchers (Barney, 1997) and continues to attract considerable contest in terms of measurement and definition (Keats \& Hitt, 1985). The problems of measurement of performance arise from its multifaceted and multidimensional nature (Ongeti, 2014).

\section{Theoretical Review}

\section{LITERATURE PREVIEW}

Several theories explain the association between internal audit and efficiency of firm. This study is underpinned on the following theories: agency theory (Adams, 1974), monitoring theory (Wallace, 1980), and policeman theory (Adams, 1974). Jensen and Meckling (1976) developed the agency theory framework that explains the association between the principal and the agent; where one part (principal) delegate tasks to another (agent). Watts and Zimmerman (1986) posit that the audit serves the interests of both shareholders as well as the management. While the shareholders own the firm, the management (agent) exercises the control of that firm. If shareholders and management each seek to maximize their utility, the agent may possibly prioritize own interests to the detriment of those of the principal. The monitoring theory explains that employees are rational, risk-averse and are selfish actors who are motivated by self-interest (Beaver, 1989).Monitoring theory posits that when the agent accepts to work on behalf of the principal, the agent is well aware that he will be monitored to ensure optimum efficiency.Wallace (1987) and Beaver (1989) explained that the monitoring theory aims to reduce problems of moral hazard and information asymmetry between the principal and the agent. The policeman theory asserts that internal auditing is responsible for searching, detecting and preventing fraud. It focuses on a designed internal audit to safeguard the assets of companies and assist in verification of accounting information for decision making purpose (Van Peursen, 2005). However, the policeman theory cannot clarify the change of auditing to confirmation of the true and fair financial statements which is currently the main focus of internal audit as it gives reassurance to management on those statements. Nevertheless, the policeman theory contributes to the study due to its advocacy of 
safeguarding the public company's assets and ensuring accountability on the part of managers of public institutions (Morgan, 1979).

\section{Empirical Review}

According to Subramaniam and Cooper (2013), test on the influence of internal audit on financial reporting in Malaysian companies using a regression analysis approach. The study findings pointed to a positive relationship between internal audit quality and irregular accruals inferring that some internal audit qualities have an important part in the financial reporting process. Though the study is a contribution to regulatory reforms with Board of directors moderating the observed relationship, the study considered the quality of financial reports and not the levels of firm financial performance as influenced by internal audit quality.

The study by Aldamen, Duncan, Kelly, McNamara, Nagel (2012) on investigating whether Board Audit committee (AC) characteristics controls the performance of firms during adverse economic downturn event such as Global Financial crisis, that used the logit regression tests to analyze the data on audit committees and the Board of directors. The findings were that smaller audit committees with more experience and financial expertise enhance firm performance. Longer serving chairs of audit committees were however found to negatively influence financial performance of firms but have positive impact where the chair of the board and other members of the Board are independent and have many years of managerial experience. Corporate governance improves audit committee character that positively affect performance especially during adverse economic shocks like the global financial crisis revealed that performance is negatively related with the number of audit committee members.

Cohen and Sayag (2010) studied the efficacy of internal audit using descriptive analysis design by researching on the following variables: industry of the firm; expertise of internal auditors; worth of audit work; independence; training and top management support. Top administration support was seen to be the major determinant of internal audit effectiveness for enhancing performance of hotels in Israel.

A cross sectional survey on 108 Israel firms that employ internal audit to determine the perceptions on internal audit function, effectiveness and determinants of internal audit effectiveness in an organisation was done by Dominic and Nonna (2011). Data on the effectiveness of internal audit were derived from the managers as respondents and data on what determines effectiveness of internal audit from the internal auditors. The results were that effectiveness of internal audit is determined to a large extent by firm organisational structure, the status and relationship of internal audit works, staffing level of internal audit department and the competencies of staff in that department. An investigation on internal audit position in the firm's organisation chart and how it enhances the audit independence and its effects on audit role in promotion of corporate structures was carried out by Sarens and Beelde (2006). The survey of Chief Audit executives in European companies used multivariate regression analysis. The findings were that, the internal audit has a wide scope, free access to information, adequate resources to monitor various company decisions and adequately advice managers, provide oversight and ensure own independence and objectivity to promote corporate governance and firm efficiency.

Van Peursen's (2005) study on how internal audit deals with the conflict of interest between the double roles of consulting and assurance service provision to management. The survey of internal Auditors in Israel hotels found out that there is tension in maintaining the two roles leading to a mix up of roles which hinders internal audit effectiveness. There are both conceptual and contextual gaps. No consideration was given to internal controls, firm 
characteristics of WSPs in Kenya and further no relationship between internal audit and fir performance was evaluated.

In the light of the foregoing, this research tested the null hypothesis below:

Ho1: The influence of internal audit on performance of water service providers in Kenya is not significant.

\section{Research Design}

\section{RESEARCH METHODOLOGY}

A cross-sectional survey was used in this study. The design was appropriate since it included data collection at a point in time which relates to two or more variables in an effort to determine associations between the variables. A survey was suited for the study because WSPs in Kenya are few but spread to all parts of the country.

\section{Population of the Study}

The population of the study was 93 water service providers in Kenya which were regulated by WASREB as at 2015. Population census was best for the research as the WSPs are few and although spread in the entire country, Kenya, data collection costs were minimal as the respondents were within reach at WASPA monthly meetings and the secondary data was readily accessible from WASREB impact assessment reports. This context was chosen because there was a prevalent manifestation of the variables in this study as alluded to by the literature reviewed (WASREB, 2014).

\section{Data Collection Instrument}

The study used both primary and secondary data. Primary data was obtained by selfadministered, pre arranged questionnaire made up of closed ended questions prepared in line with the goals, theories upon which the study was anchored, empirical studies and corresponding hypotheses of the study. Study assistants were recruited and trained. The data collection instruments were delivered to the Chief Executive Officer who was considered as best placed to have the required information. According to Newbert (2008), one respondent who is knowledgeable on matters regarding a study is well placed to be a key informant. Secondary data on performance of WSPs was collected for the period 2011 to 2015 from WASREB impact assessment reports. An average of that data for the five years showing the performance of each WSP was computed and analyzed. The primary data collected on internal audit, institutional characteristics and internal controls was regressed on performance of the WSP to establish the linkages.

\section{Data Analysis}

Data collected was cleaned and edited to ensure it was complete. It was then coded and entered into the statistical package for social sciences (SPSS) software version 21 and analysed through descriptive and inferential statistics. Linear regression models were used to evaluate the association between variables as hypothesized in the study at $5 \%$ level of significance.

\section{Empirical Model}

The objective was to establish the association between internal audit and performance of water service providers in Kenya. The dependent- independent variables relationship is modelled as:

Where:

$$
\mathrm{P}=a+\beta_{1} X_{1}+\varepsilon
$$

$\mathrm{P}=$ Performance 
$\beta_{1}$ is beta coefficient

$a=$ intercept

$\varepsilon=$ Error term

$\mathrm{X}_{1}=$ internal audit (composite)

\section{Response Rate}

\section{RESULTS AND DISCUSSION}

A total of 93 questionnaires were circulated to the 93 WSPs that were the target population for the study. A total of 73 questionnaires were correctly filled and returned. This represented a response rate of 78\%. According to Borg (2007) a response rate of 50 percent in a survey is adequate. The response rate of $78 \%$ was considered adequate as it was above the benchmark of 50 percent. This implied that the findings of this study were representative of the overall population.

\section{Descriptive Analysis for Internal Audit}

The researcher sought to carry out three types of analysis on internal audit. The pertinent results are presented below.

Table 1: Descriptive Statistics on Oversighting Internal Audit

\begin{tabular}{|l|c|c|c|c|}
\hline & $\mathbf{N}$ & Mean & $\begin{array}{c}\text { Std. } \\
\text { Deviation }\end{array}$ & $\begin{array}{c}\text { Coefficient of } \\
\text { Variation }\end{array}$ \\
\hline $\begin{array}{l}\text { 1. } \\
\text { The policies and practices developed by the } \\
\text { internal audit for risk management are approved } \\
\text { by the audit board }\end{array}$ & 73 & 3.758 & 1.313 & $35 \%$ \\
\hline $\begin{array}{l}\text { 2. } \\
\text { The audit board approves audit program before its } \\
\text { forwarded to the board for implementation }\end{array}$ & 73 & 3.773 & 1.310 & $35 \%$ \\
\hline 3. $\begin{array}{l}\text { The audit boards review performance of internal } \\
\text { auditors }\end{array}$ & 73 & 3.652 & 1.295 & $35 \%$ \\
\hline $4 . \quad \begin{array}{l}\text { The auditboard meets with internal auditors and } \\
\text { management on a regular basis to discuss issues of } \\
\text { concern that may arise }\end{array}$ & 73 & 3.485 & 1.438 & $41 \%$ \\
\hline $5 . \quad \begin{array}{l}\text { The audit board establishes procedures for } \\
\text { accepting confidential information like whistle } \\
\text { blowing }\end{array}$ & 73 & 2.742 & 1.481 & $54 \%$ \\
\hline 6. $\begin{array}{l}\text { Audit committee reports to the board of Directors } \\
\text { regularly }\end{array}$ & 73 & 4.283 & 1.133 & $26 \%$ \\
\hline
\end{tabular}

Source: Author (2018)

The results in table 1, indicates that internal audit is over sighted by other board organs to a large extent. Regular reports to the board by internal audit (Mean $=4.283$, SD $=1.133$ ), Audit committee approval of audit report before it is forwarded to the board (Mean $=3.773, \mathrm{SD}=$ 1.310 ) and Audit board reviews performance of internal auditors (Mean = 3.652, $\mathrm{SD}=1.259$ ). On procedures established by the board, the variation was high above the average (C.V=54\%) while there was a less variability on audit committee reporting to the board regularly at $26 \%$.

\section{Provision of Resources to Internal Audit Function}

The researcher computed descriptive statistics on the aspect of provision of resources to the internal audit function. Table 2 below shows the results of this analysis. 
Table 2: Descriptive Statistics on Provision of Resources

\begin{tabular}{|c|c|c|c|c|}
\hline & $\mathbf{N}$ & Mean & $\begin{array}{c}\text { Std. } \\
\text { Deviation }\end{array}$ & $\begin{array}{c}\text { Coefficient } \\
\text { of Variation }\end{array}$ \\
\hline 1. & The audit board approves the budget of \\
internal audit department & 73 & 3.576 & 1.313 & $37 \%$ \\
\hline $2 . \quad \begin{array}{l}\text { The audit board determines } \\
\text { compensation and benefits of chief } \\
\text { internal auditor }\end{array}$ & 73 & 2.813 & 1.271 & $45 \%$ \\
\hline 3. $\begin{array}{l}\text { The audit board ensures the internal } \\
\text { audit function has audit resources }\end{array}$ & 73 & 3.554 & 1.118 & $31 \%$ \\
\hline
\end{tabular}

\section{Source: Author (2018)}

As indicated by the likert scale item responses in Table 2, the respondents indicate that to a moderate extent, the audit board determines compensation and benefits of the chief internal auditor (Mean $=2.813, \mathrm{SD}=1.271$ ). Two likert item responses show that to a large extent, audit board approves budget of internal audit department (Mean $=3.576, \mathrm{SD}=1.313$ ) and the audit board ensures that the internal audit function has resources (Mean $=3.554, \mathrm{SD}=1.118$ ). On determining compensation and benefits of chief internal auditor by audit board the variation stood at $45 \%$ while audit board ensuring the internal audit function has audit resources was at $31 \%$.

\section{Competency of Chief Internal Auditor}

The study envisaged to establish the competency of chief internal auditor and got the results presented in Table 3

Table 3: Descriptive Statistics on Competency of Chief Internal Auditor

\begin{tabular}{|ll|c|c|c|c|}
\hline & $\mathbf{N}$ & $\mathbf{M e a n}$ & $\begin{array}{c}\text { Std. } \\
\text { Deviation }\end{array}$ & $\begin{array}{c}\text { Coefficient } \\
\text { of Variation }\end{array}$ \\
\hline $\begin{array}{l}\text { The audit board is responsible for making } \\
\text { sure competent chief internal auditor is hired }\end{array}$ & 73 & 3.631 & 1.257 & $37 \%$ \\
\hline $\begin{array}{l}\text { The audit board monitors training needs of } \\
\text { audit staff }\end{array}$ & 73 & 3.159 & 1.221 & $39 \%$ \\
\hline $\begin{array}{l}\text { The audit board assesss the perfomance of the } \\
\text { chief internal auditor regularly }\end{array}$ & 73 & 3.516 & 1.297 & $37 \%$ \\
\hline
\end{tabular}

Source: Author (2018)

As presented in table 3 above, the respondents indicate that to a moderate extent, the audit board monitors training needs of audit staff (Mean $=3.159, \mathrm{SD}=1.221$ ) and to a large extent, the audit board ensures competence in hiring the chief internal auditor (Mean $=3.631, \mathrm{SD}=$ 1.257) and audit board assess performance of chief internal auditor regularly (Mean $=3.516$, $\mathrm{SD}=1.297$ ). On Competency of Chief Internal Auditor the range on variability was between $37 \%$ and $39 \%$, hence the audit board monitoring training needs of audit staff had the highest varibility.

\section{Individual Sub- Variable Descriptive Statistics}

The study collected primary data on specific internal audit attributes and internal control mechanisms among the identified water service providers. These internal audit attributes included; assurance services, compliance policies, consulting management, independence and objectivity. The internal control mechanisms included; segregation of duties, IT controls, human resources controls and operating procedures. The descriptive statistics of the responses to the specific questions based on a survey of 93 WSPS with N being 73 WSPs are indicated in tables 4 to 6 below. 


\section{Assurance Services}

The researcher carried a study on assurance services and obtained the results below.

Table 4: Descriptive Statistics on Assurance Services

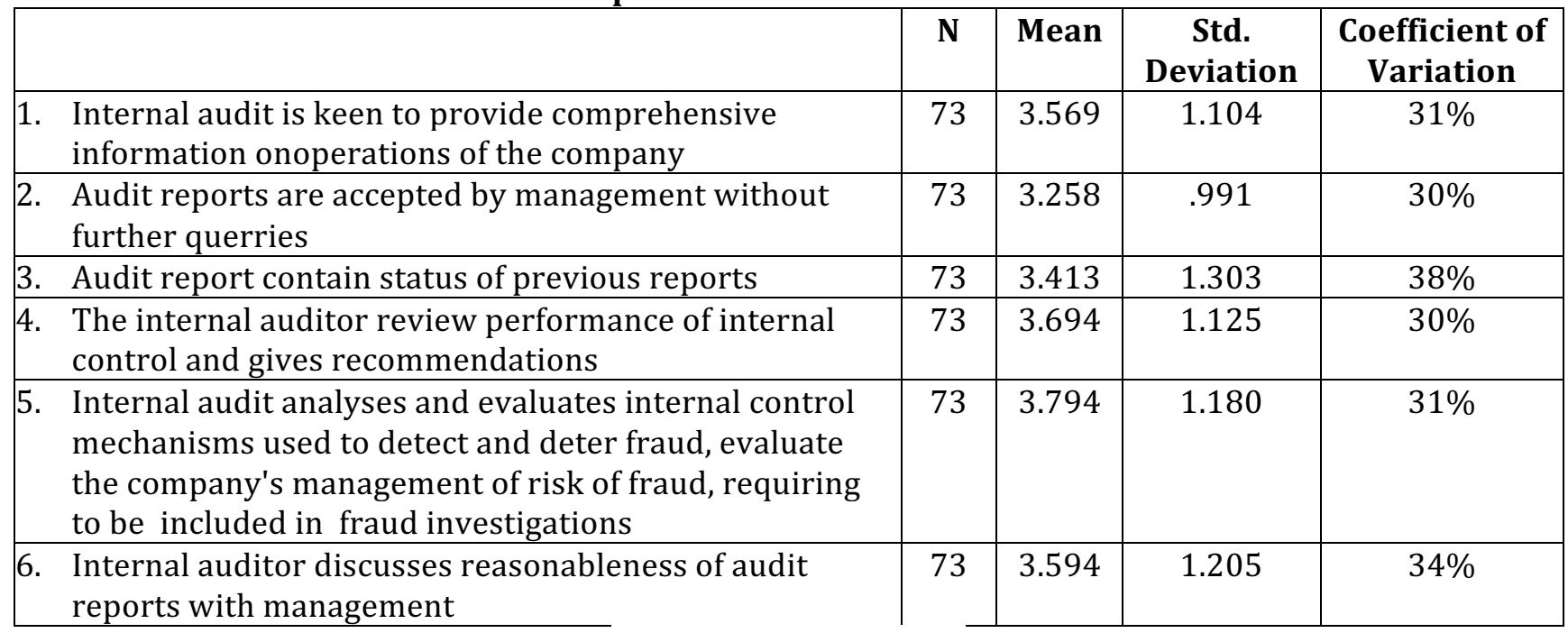

Source: Author (2018)

Four likert item responses by the respondents (CEO) on assurance services all rated to a large extent. As presented in Table 5 above, Assisting management with analysis of internal controls for fraud detection (Mean $=3.794, \mathrm{SD}=1.180$ ), review of performance of internal audit operations (Mean $=3.694, \mathrm{SD}=1.125)$, discussion of internal audit reports with management (Mean $=3.594, \mathrm{SD}=1.205)$ and provision of comprehensive information on organisational procedures $($ Mean $=3.569, \mathrm{SD}=1.104)$ are internal audit practices existent to a large extent in the companies. Two of the likert responses indicate that provision of previous status reports (Mean $=3.413, \mathrm{SD}=1.303$ ) and management acceptance of reports without further queries (Mean $=3.258, \mathrm{SD}=0.991$ ) are experienced by the respondents to a moderate extent. On assurance services the item on whether audit reports contain status of previous reports had the highest variability at $38 \%$.

\section{Compliance to Policies}

Descriptive analysis on compliance policies was conducted and yielded the following results.

Table 5: Descriptive Statistics on Compliance Policies

\begin{tabular}{|ll|c|c|c|c|}
\hline & N & Mean & $\begin{array}{c}\text { Std. } \\
\text { Deviation }\end{array}$ & $\begin{array}{c}\text { Coefficients } \\
\text { of Variation }\end{array}$ \\
\hline 1 & $\begin{array}{l}\text { The chief internal auditor is keen on } \\
\text { safeguarding adherence to policies and } \\
\text { procedures }\end{array}$ & 73 & 3.641 & 1.213 & $33 \%$ \\
\hline 2 & $\begin{array}{l}\text { Audit plan is regularly reviewed to ensure } \\
\text { compliance with IIA standards of reporting }\end{array}$ & 73 & 3.286 & 1.224 & $37 \%$ \\
\hline 3 & $\begin{array}{l}\text { The chief internal auditor continuously } \\
\text { review the operating procedures and gives } \\
\text { recommendations }\end{array}$ & 73 & 3.500 & 1.234 & $35 \%$ \\
\hline $4 \begin{array}{l}\text { The internal audit assesss the performance } \\
\text { of policy implementation in the company }\end{array}$ & 73 & 3.460 & 1.105 & $32 \%$ \\
\hline
\end{tabular}

\section{Source: Author (2018)}

As presented in Table 6, two likert item responses indicated that the chief internal auditor safeguards adherence to policies and procedures (Mean $=3.641, \mathrm{SD}=1.213$ ) and continuously 
reviews operating procedures and gives recommendations (Mean $=3.500, \mathrm{SD}=1.234$ ) to a large extent

Two likert item responses indicate that to a moderate extent, the internal audit assesses performance of policy implementation in the company (Mean $=3.460$, SD $=1.105$ ) and audit plan is regularly reviewed to ensure compliance with international reporting standards (Mean $=3.286, \mathrm{SD}=1.224)$. On compliance policies the item that, audit plan is regularly reviewed to ensure compliance with IIA standards of reporting, had the highest variability.

\section{Consulting Management}

The researcher conducted a study on the impact of consulting management on matters pertaining internal audit.

Table 6: Descriptive Statistics on Consulting Management

\begin{tabular}{|ll|c|c|c|c|}
\hline & Mean & $\begin{array}{c}\text { Std. } \\
\text { Deviation }\end{array}$ & $\begin{array}{c}\text { Coefficients } \\
\text { of Variation }\end{array}$ \\
\hline 1 & $\begin{array}{l}\text { The chief internal auditor is constantly } \\
\text { consulted on best practices of financial } \\
\text { management }\end{array}$ & 73 & 3.031 & 1.168 & $39 \%$ \\
\hline 2 & $\begin{array}{l}\text { The chief internal auditor is proactive in } \\
\text { initiating measures that curb frauds,and } \\
\text { reduce potential waste in resources }\end{array}$ & 73 & 3.344 & 1.185 & $35 \%$ \\
\hline $3 \begin{array}{l}\text { The chief internal auditor provides insights } \\
\text { that focus on areas of enhanced } \\
\text { performance }\end{array}$ & 73 & 3.672 & 1.222 & $33 \%$ \\
\hline $4 \begin{array}{l}\text { The management implement proactively } \\
\text { internal auditors recommendations }\end{array}$ & 73 & 3.594 & 1.065 & $30 \%$ \\
\hline 5 & $\begin{array}{l}\text { The management constantly consults } \\
\text { internal auditors on risk management } \\
\text { strategies }\end{array}$ & 73 & 3.172 & 1.203 & $38 \%$ \\
\hline
\end{tabular}

\section{Source: Author (2018)}

Table 6 indicates that to a large extent, internal audit provides insights that focus on areas of performance $($ Mean $=3.672, \mathrm{SD}=1.222$ ) and management proactively implements internal auditors recommendations (Mean $=3.594, \mathrm{SD}=1.065$ ). From three likert item responses in the table above, internal audit to a moderate extent proactively initiates measures to curb frauds and reduce potential waste in resources (Mean $=3.344, \mathrm{SD}=1.185$ ), are constantly consulted by management on risk management strategies (Mean $=3.172, \mathrm{SD}=1.203$ ) and are constantly consulted on best practices of financial management (Mean $=3.031$, SD $=1.168$ ). The item on whether the chief internal auditor constantly consults on best practices of financial management had the highest variabilty at 39\% while on whether management implement proactive internal audit recommendations had the smallest variabilty of $30 \%$.

\section{Independence}

The study aimed at establishing the independence of internal auditor. 
Table 7: Descriptive Statistics on Independence

\begin{tabular}{|ll|c|c|c|c|}
\hline & $\mathbf{N}$ & Mean & $\begin{array}{c}\text { Std. } \\
\text { Deviation }\end{array}$ & $\begin{array}{c}\text { Coefficients } \\
\text { of Variation }\end{array}$ \\
\hline 1 & $\begin{array}{l}\text { The head of internal audit reports functionally to the } \\
\text { audit board and administratively to the chief } \\
\text { executive officer }\end{array}$ & 73 & 4.333 & 1.188 & $27 \%$ \\
\hline $\begin{array}{l}\text { The boards through the audit board approves the } \\
\text { internal audit budget }\end{array}$ & 73 & 3.742 & 1.267 & $34 \%$ \\
\hline $3 \begin{array}{l}\text { The boards through the audit board approves the } \\
\text { budget plan and reviews audit plan }\end{array}$ & 73 & 3.594 & 1.306 & $36 \%$ \\
\hline $4 \begin{array}{l}\text { The internal auditor determines the scope of } \\
\text { auditing, and communicating results independently }\end{array}$ & 73 & 3.862 & 1.171 & $30 \%$ \\
\hline 5 & $\begin{array}{l}\text { Audit board reviews the annual progress of the audit } \\
\text { activities in relation to the audit plan }\end{array}$ & 73 & 3.466 & 1.341 & $39 \%$ \\
\hline 6 & $\begin{array}{l}\text { internal audit function has been funded in away that } \\
\text { promotes objectivity and consistency in quality of its } \\
\text { delivery }\end{array}$ & 73 & 3.463 & 1.206 & $35 \%$ \\
\hline
\end{tabular}

\section{Source: Author (2018)}

Table 7 presents four likert responses where respondents indicate to a large extent that the head of internal audit reports functionally to audit board committee and administratively to the CEO (Mean $=4.333, \mathrm{SD}=1.188$ ), the internal auditor is free from interference in scoping wok and communicating results (Mean $=3.862$, $\mathrm{SD}=1.171$ ), the board through the audit board approves the internal audit budget (Mean $=3.742, \mathrm{SD}=1.267$ ) and the boards through the audit board approves resource plan and reviews audit plans (Mean $=3.594, \mathrm{SD}=1.306$ ). The respondents indicate that to a moderate extent, audit board reviews annual progress of audit activities in relation to audit plan (Mean $=3.466, \mathrm{SD}=1.341$ ) and internal audit function has been funded in a way that promotes objectivity and consistency (Mean $=3.463, \mathrm{SD}=1.206$ ). On Independence, on whether audit board reviews the annual progress of the audit activities in relation to the audit plan had the highest variability of $39 \%$ while on assessing whether the head of internal audit reports functionally to the audit board committee and administratively to the CEO had smallest variability of $30 \%$.

\section{Objectivity}

The researcher sought to find out whether there is objectivity in practice by the internal auditor.

Table 8: Descriptive Statistics on Objectivity

\begin{tabular}{|c|c|c|c|c|}
\hline & $\mathbf{N}$ & Mean & $\begin{array}{c}\text { Std. } \\
\text { Deviation }\end{array}$ & $\begin{array}{l}\text { Coefficients } \\
\text { of Variation }\end{array}$ \\
\hline $\begin{array}{l}\text { 1. The renumeration and terms of service for chief } \\
\text { internal auditor are approved by the audit board }\end{array}$ & 73 & 3.215 & 1.484 & $46 \%$ \\
\hline $\begin{array}{l}\text { 2. The internal auditor is prohibited from auditing } \\
\text { works which he has executed }\end{array}$ & 73 & 3.322 & 1.559 & $47 \%$ \\
\hline $\begin{array}{l}\text { 3. The chief internal auditor has direct access to all } \\
\text { firm information without restrictions }\end{array}$ & 73 & 4.062 & 1.309 & $32 \%$ \\
\hline $\begin{array}{l}\text { 4. The chief internal auditor cannot review the } \\
\text { operations conducted by a relative }\end{array}$ & 73 & 3.422 & 1.434 & $42 \%$ \\
\hline
\end{tabular}

Source: Author (2018)

As presented in Table 8, the interviewees indicated that to a large extent, the internal auditor has direct access to all firm information without restrictions (Mean $=4.062$, SD $=1.309$ ). The respondents indicate that to amoderate extent, chief internal auditor can not review the 
procedures conducted by a relative (Mean $=3.422, \mathrm{SD}=1.434$ ), internal auditor is prohibited from auditing works he has executed (Mean $=3.322, \mathrm{SD}=1.559$ ) and renumeration and terms of service for chief internal auditor are approved by the audit committe (Mean $=3.215$, $\mathrm{SD}=$ 1.484). A high variability $47 \%$ was noted on whether the internal auditor is prohibited from auditing works which he has executed a low variability of $32 \%$ was noted on whether the chief internal auditor has direct access to all firm information without restrictions.

\section{Performance of Water Service Providers}

The researcher examined the performance of WSPs in Kenya using DEA model with output/input relationship. Data envelop analysis which a non-parametric technique is assigned a performance score ranging from 0 to 1 to the decision making units.

Table 13: Performance of the WSPs in Kenya

\begin{tabular}{|l|c|c|}
\hline Range/Statistic & Frequency & Value \\
\hline 0.0 to 0.3 & 4 & $5.5 \%$ \\
\hline 0.31 to 0.6 & 12 & $16.4 \%$ \\
\hline 0.61 to 0.9 & 41 & $56.2 \%$ \\
\hline 0.91 and above & 16 & $21.9 \%$ \\
\hline Total number of WSPs & 73 & $100 \%$ \\
\hline Arithmetic Mean & & 0.7259 \\
\hline Standard Deviation & & 0.2069 \\
\hline Maximum & & 1.0000 \\
\hline Minimum & & 0.1493 \\
\hline
\end{tabular}

Source: Author (2018)

Table 13 shows the outputs used as: Water coverage, Revenue collection performance; Staff performance; Metering ratio; Non Revenue Water; Revenue turnover; and Number of hours of Water supply while the Inputs used were Personnel costs, Operating and Maintenance costs.

The observation is shown in Table 13 above. Fifty six percent (56\%) of the WSPs had performance of between .61 and 0.9 which is above average. Sixteen percent of the WSPs have between .31 and .60 performance which is moderate. The highest performance was 1.0 and the lowest was 0.15. The DEA performance is captured in Appendix V.

\section{HYPOTHESES TESTING AND DISCUSSION OF FINDINGS Influence of Internal Audit on Organisational Performance}

The first specific goal of the study was to determine the effect of internal audit on performance of Water Service Providers in Kenya. The study postulated that the relationship between performance and internal audit attributes namely; assurance services, compliance policies, consulting management, independence and objectivity were not significant. Organisational performance was measured through the performance ratio of each water service provider. Simple regression analysis was used to assess if there is linear relationship between the internal audit (independent variables: assurance services, compliance policies, consulting, independence and objectivity) and whether they predicted performance ratio (dependent variables) of the water service providers of Kenya.

Hypothesis: The influence of internal audit on performance of water service providers in Kenya is not significant. 
The prediction equation was given as: $\mathrm{P}=a+\beta_{1} X_{1}+\varepsilon$

Where: $\mathrm{P}=$ Performance

$\beta_{1}$ is beta coefficient

$a=$ intercept

$\varepsilon=$ Error term

$\mathrm{X}_{1}=$ internal audit (composite)

The result of the regression model are given in Tables 5.1, 5.2 and 5.3.

\section{Goodness of Fit}

Determination of the influence of internal audit on performance of Water Service Providers was conducted and obtained results in Table 15

Table 15: Model Goodness of Fit of Internal Audit Practices and Perfomance

\begin{tabular}{|c|c|c|c|c|}
\hline Model & $\mathrm{R}$ & $\mathrm{R}$ Square & Adjusted R Square & Std. Error of the Estimate \\
\hline 1 & $.336^{\mathrm{a}}$ & .113 & .101 & .17739 \\
\hline
\end{tabular}

\section{Source: Author (2018)}

The regression results in Table 15 shows an adjusted $R^{2}=0.101, F(1,72)=9.047, p<0.05$. The outcome of the regression analysis in Table 15 shows that $10.1 \%$ of variations in organisational perfomance is explained by variations in internal audit amongst the WSPs while $89.9 \%$ is accounted for by other factors outside the study. The relationship is statistically significant $(\mathrm{p}<0.05)$ and thus we reject the null hypothesis and accept the alternative hypothesis. This shows that internal audit influences performance of water service providers in kenya.

\section{ANOVA}

Table 16 tested the goodness of fit of the model by interpreting the p-value as well as the beta coefficients.

Table 16: Model Overall Significance of Internal Audit Practices and Organisational Perfomance

\begin{tabular}{|l|c|c|c|c|c|}
\hline & Sum of Squares & $\mathrm{df}$ & Mean Square & $\mathrm{F}$ & $\mathrm{p}$-value. \\
\hline Regression & .285 & 1 & .285 & 9.047 & $.004^{\mathrm{b}}$ \\
\hline Residual & 2.234 & 71 & .031 & & \\
\hline Total & 2.519 & 72 & & & \\
\hline
\end{tabular}

Source: Author (2018)

As presented in table 17, the regression model one shows a statistically significant positive relationship between internal audit and organisational perfomance $(\beta=0.336, t=3.008, p<0.05)$ implying that for every unit increase in internal audit, there is an expected increase in performance that proxy organisational perfomance by 0.336 units.

Table 17: Model Regression Coefficients of Internal Audit Practices and Organisational Perfomance

\begin{tabular}{|l|l|c|c|c|c|c|}
\hline \multicolumn{2}{|c|}{} & \multicolumn{2}{|l|}{$\begin{array}{l}\text { Unstandardized } \\
\text { Coefficients }\end{array}$} & $\begin{array}{l}\text { Standardized } \\
\text { Coefficients }\end{array}$ & \multirow{2}{*}{ Sig. } \\
\cline { 2 - 6 } & B & Std. Error & Beta & & \\
\hline & (Constant) & .385 & .076 & & 5.070 & .000 \\
\cline { 2 - 6 } & $\begin{array}{l}\text { Internal audit } \\
\text { practices }\end{array}$ & .336 & .021 & .336 & 3.008 & .004 \\
\hline
\end{tabular}

Source: Author (2018) 
Based on the results of the regression analysis which shows a statistically significant positive association between internal audit and organisational performance, the study concluded that there is a significant relationship between internal audit and performance of water service providers in Kenya resulting to the rejection of hypothesis one $\left(\mathrm{H}_{1}\right)$. This finding is consistent with earlier findings by Donaldson and David (1991), Serems and Bebedde (2006), Cohen and Sayag (2010) which confirmed that existence of internal audit in organisations influence their performance.

\section{CONCLUSIONS AND RECOMMENDATIONS}

This study set out to examine the relationships between internal audit and performance of water service providers in Kenya. The study was anchored on Monitoring, Agency and Policeman theories. Primary and secondary data were collected from the Water service providers in Kenya. Out of 93 questionnaires issued to the respondents, 73 (78\%) respondents filled and the data collected used for the analysis. Simple regression analysis results led to rejection of the hypothesis and concluded that internal audit significantly influence firm performance. Therefore, for improved performance of the WSPs, the firm managers and directors should ensure existence of sound internal audit practices including; assurance services, compliance policies, consulting management, independence and objectivity. There should also be an audit committee that oversee internal audit, provides resources and ensures competency of the chief internal auditor.

\section{SUGGESTIONS FOR FURTHER STUDY}

This study collected and analysed secondary data covering five years only with respect to performance. Primary data was collected using a five point Likert type scale. There is need to extend this study over a longer period of time to allow for random effects influence of internal audit on firm performance. Future studies may use both open ended and closed ended questionnaire or use any other methods to collect primary data rather than relying on five point likert type scale.

Further studies should model other forms of relationships between the study variables including curvilinear relationships and dual causality relationships as well as introducing other characteristic variables to the study model. Third, a focus on a different organisational setting is also recommended to bring out the differential effect of internal audit on firm performance.

It is necessary and core to enquire into the existence of internal audit practices across time and across industrial settings other than public companies and how this affects the overall firm performance. Fourth, the study focused on public WSPs under the assumption that private WSPs perform better and have sound internal audit practices and internal controls. It may be necessary to carry out a study comparing the performance of Public sector and Private sector WSPs.

\section{References}

Abushaiba, I. A. \& Zainuddin, Y. (2012). Performance measurement design, competitive capability, and performance consequences: a conceptual like. International Journal of Business and Social Science, 3(11), 184-193.

.Adams, K. (1974). Measuring the Prevalence of Police Abuse of Force. in Police Violence: Understanding and Controlling Police Abuse of Force, edited by W. A. Geller and H. Toch. New Haven, CT: Yale University Press. 52-93

Alkins, S. K. (2011). An examination of government internal audit's role in improving financial performance. Public Finance and Management, 11 (4), 306-337

Amit, R. \& Shoemaker, P. (1993). Strategic Assets and Organizational Rent. Strategic Management Journal, 14(1), 33-46. 
Badara, M. \& Saidin, S. (2013). Improving the existing functions of internal audit at organizational level. International Journal of Arts and Commerce, 1(6), 38-46.

Baltaci, M. \& Yilmaz, S. (2006). Keeping an eye on subnational government: internal controls and audit at local levels. World Bank Institute Washington DC

Belay, Z. (2007). A study on effective implementation of internal audit function to promote good governance in the public sector. Presented to the The Achievements, Challenges, and Prospects of the Civil Service Reform Program Implementation in Ethiopia, Conference Ethiopian Civil Service College Research, Publication and Consultancy Coordination Office.

Colbert, J. (2002). Corporate governance: Communications from internal and external auditors. Managerial Auditing Journal, 17(3), 147-152.

Cohen, A. \& Sayag, G. (2010). The Effectiveness of internal auditing: An empirical examination of its determinants in Israeli organizations. Australian Accounting Review, 54(20), 296-307.

Collis, J. \& Hussey, R. (2003). Business research: A practical guide for undergraduate and postgraduate students. Palgrave Macmillan, Houndmills, Basingstoke, Hampshire.

Cooper, R. D. \& Schindler, P. (2003). Business research methods ( $8^{\text {th }}$ Ed.). New Delhi: Tata McGraw-Hill. COSO, (1992). Internal control-integrated framework, committee of sponsoring organizations. New York, NY. COSO. (2013). Internal Control-Integrated Framework.

Dixon, J. R. (1990). The new performance challenge: Measuring operations for worldclass competition. Irwin Professional Pub.

Dominic, S. B. Soh, Nonna Martinov-Bennie, (2011). The internal audit function: Perceptions of internal audit roles, effectiveness and evaluation. Managerial Auditing Journal, 26(7), 605-622.

Donaldson, L. \& Davis J. H. (1991). Stewardship theory or agency theory: CEO governance and shareholder returns. Australian Journal of Management, 16(1), 49-65.

Donaldson, L. (1995). American Anti-Management Theories of Organization: A Critique of Paradigm Proliferation. Cambridge: Cambridge University Press.

Duffy, J. A. M., Fitzsimmons, J. A. \& Jain, N. (2006). Identifying and studying best performance service benchmarking. An International Journal, 13 (3), 232-251.

Eisenhardt, K. M. (1989). Agency theory: An assessment and review. Academy of Management Review, 14(1), 5774.

Eko, S. \& Hariyanto, E. (2011). Relationship between Internal Control, Internal Audit, and Organization Commitment with Good Governance: Indonesian Case. Managerial Auditing Journal, 32(5), 6-13.

Emasu, S. (2007). Public financial management - Concepts and Practices, ACCA International Public Sector Bulletin, 7, 6-10

Fama, E. (1980). Agency problems and the theory of the firm. Journal of Political Economy, 88(2), 288-307.

Field, A. P. (2009). Discovering statistics using SPSS, $3^{\text {rd }}$ ed. London: Sage.

Fiedler, K. M. (1964). A Theory of leadership effectiveness. New York: McGraw-Hill.

Fond, R, \& You, H. (2010). The federal deposit insurance corporation improvement act, Bank internal controls and financial reporting quality. Journal of Accounting and Economics, 49(1-2), 75-83.

Gaa, J. C. (1991). The expectations game: Regulation of auditors by government and the Profession. Critical Perspective of Accounting, 2(1), 83-107.

Galbraith, J. R. (1973). Designing Complex Organizations. Addison-Wesley.

Gamage, C. T. A., Lock K. L. \& Fernando A. A. J. F. (2014). Proposed research framework: effectiveness of internal control system in state commercial banks in Sri Lanka. International Journal of Scientific Research and Innovative Technology, 1(5), 25-44

Hays, D. \& Davis, D. (2004). The voluntary choice of an auditor of any level of quality. Auditing: A Journal of Practice and Theory, 23(2), 39-55.

IIA, (2010). Measuring internal audit effectiveness and efficiency. IPPF-Practice guide.The Institute of Internal Auditors. 
Institute of Internal Auditors (1999). Definition of Internal Auditing. Altamonte Springs, FL: The Institute of Internal Auditors.

Kothari, C. R. (2004). Research methodology, methods and techniques, $2^{\text {nd }}$ ed. New Delhi: New Age International (P) Ltd.

Lanchaster, G. (2005). Research methods in management: A concise introduction to research in management and business consultancy.

Majumdar, S. K. (1997). The impact of size and age in firm performance: some evidence from India. Review of Industrial Organization, 12, 231 - 252.

Mawanda, S. P. (2008). Effects of internal control systems on financial performance in an institution of higher learning in Uganda: A case of Uganda Martyrs University. Unpublished thesis, Uganda Matyrs University

McCall, S. M. (2002). The auditor as a consultant. The Internal Auditor Journal, 59 (6), 35-39.

Management, 2(10), 709-725.

Stewart, J., \& Yeo, T. (2001). Two Factors Affecting Internal Audit Independence and Objectivity: Evidence from Singapore. International Journal of Auditing, 5(2), 107-125.

Theofaris, K. D. G. \& Glovanis, N. (2011). Evaluation of the effectiveness of internal audit in Greek hotel business. International Journal of Economic Sciences and

Venkatraman, N. \& Ramanujam, V. (1981). Measurement of business performance in strategy research. Comparison approaches. Academy of Management Review, 11(4), 801-814.

Wallace, W. (1980). The economic role of the audit in free and regulated markets. Research Journal in Accounting Regulations, 15, 39-68.

Watts, R \& J. Zimmerman (1986). Positive accounting theory. Englewood Cliffs, New Jersey: Prentice-Hal

Wee, Goh, B. (2009). Audit committees, board of directors, and remediation of material weaknesses in internal control. Contemporary Accounting Research, 26 (2), 549-579

Williams, B., Brown, T., \& Onsman, A. (2012). Exploratory factor analysis: A five step guide for novices. Australian Journal of Paramedicine, 8(3), 1-13. 